\title{
CJLT

\section{Investigating the Benefits and Challenges of Using Laptop Computers in Higher Education Classrooms \\ Étude sur les avantages et les défis associés à l'utilisation d'ordinateurs portables dans les salles de classe d'enseignement supérieur}

Robin Holding Kay, University of Ontario Institute of Technology

Sharon Lauricella, University of Ontario Institute of Technology

\begin{abstract}
The purpose of this study was to investigate the benefits and challenges of using laptop computers (hereafter referred to as laptops) inside and outside higher education classrooms. Quantitative and qualitative data were collected from 156 university students (54 males, 102 females) enrolled in either education or communication studies. Benefits of using laptops in class were active note taking, particularly when instructors provided materials ahead of time, searching for academic resources, use of subject-specific software, communicating and sharing information with peers, and engaging with online interactive tools. Challenges of using laptops inside the class included surfing the web for personal reasons, social networking with peers and, to a lesser extent, entertainment in the form of watching video podcasts or playing games. Benefits were reported $30 \%$ more often than challenges inside the classroom. Benefits of using laptops outside of class included collaboration with peers, increased productivity, and conducting research. Challenges of using laptops outside of class included surfing the web for personal reasons, social networking, and entertainment. Benefits and challenges were reported equally often outside the classroom. More research needs to be conducted on the extent to which distractions impede learning and productivity inside and outside the class.
\end{abstract}

Keywords: laptop; evaluate; assess; pedagogy; benefit; challenge; higher education; college; university

\section{Résumé}

Cette étude avait pour but d'examiner les avantages et les défis associés à l'utilisation d'ordinateurs portables à l'intérieur et à l'extérieur des salles de classe d'enseignement supérieur. Des données quantitatives et qualitatives ont été recueillies auprès de 156 étudiants universitaires (54 hommes, 102 femmes) inscrits dans des programmes d'éducation ou de communication. Les 
avantages de l'utilisation d'ordinateurs portables en classe incluaient la prise active de notes, en particulier lorsque les instructeurs fournissaient la documentation à l'avance, la recherche de ressources universitaires, l'utilisation de logiciels spécifiques, la communication et le partage d'informations entre pairs, ainsi que l'utilisation active d'outils interactifs en ligne. Les défis incluaient le fait que les étudiants naviguent sur le web pour des raisons personnelles, utilisent les réseaux sociaux avec des pairs et, dans une moindre mesure, se divertissent en regardant des podcasts ou en jouant à des jeux vidéo. Les avantages ont été beaucoup plus souvent signalés que les défis. Les bénéfices de l'utilisation d'ordinateurs portables en dehors des cours incluaient la collaboration entre les pairs, une productivité accrue et la recherche en ligne. Les défis de l'utilisation d'ordinateurs portables en dehors des cours comprennent le fait que les étudiants naviguent sur le web pour des raisons personnelles, utilisent les réseaux sociaux et se divertissent. Dans le cas de l'utilisation des portables en dehors des salles de classe, les avantages et défis ont été signalés de manière égale. Des recherches supplémentaires doivent être menées pour déterminer dans quelle mesure les distractions entravent l'apprentissage et la productivité à l'intérieur et à l'extérieur de la salle de classe.

\section{Introduction}

In 2013, almost $90 \%$ of students attending a university or college owned a laptop computer, making it the most commonly owned technological device (Dahlstrom, Walker, \& Morgan, 2013). At least three reasons account for the almost ubiquitous use of laptops. First, today's higher education students, referred to as the "net generation," (Tapscott, 2008) use computers daily for an extensive range of social, entertainment, economic, and educational activities. This reliance on technology leads to an inevitable and sometimes insatiable desire for anytime, anywhere access to technology and the Internet (Montgomery, 2009; Palfrey \& Gasser, 2008; Tapscott, 2008). Second, many college and universities offer wireless access to the Internet through their campuses permitting students to research, collaborate and collect information whenever and wherever they wish (McCrea, 2010). Third, the price of laptop computers has dropped to the point where almost any university or college student can afford one (Eitelbach, 2012; Wordman, 2012).

The use of laptops devices in the classroom is supported by a wide-range of learning theories. For example, laptops allow students to communicate and collaborate with their peers in a variety of ways, anytime, anyplace, supporting Lave \& Wenger's (1998) communities of practice model of learning. In addition, having a laptop permits a student to engage in interactive, knowledge building activities based on subject-specific software or web-based learning tools thereby supporting a constructivist approach to learning (Bruner, 1996). Furthermore, a laptop combined with wireless access lets students search for a wide array of learning resources and information that would be essential to problem-based learning (Barrows \& Tamlyn, 1980; Savery \& Duffy, 1995) or partnering (Prensky, 2010). Moreover, the use of laptops coupled with the wide array of social networking tools provide an opportunity for students to learn collaboratively, an approach that is supported by social development theory (Vygotsky, 1978) and cooperative learning (Johnson \& Johnson, 1994). Finally, the idea of distributed cognition where knowledge is disseminated across objects, individuals, artefacts, and tools (Hutchins, 
1995; Perry, 2003) is well served by served by having a connected laptop in the classroom that provides access to sources of knowledge that would otherwise be unavailable.

Despite the ubiquity of laptops in higher education and their potential to support a widerange of well-established approaches to learning, limited research has been conducted how these tools support or inhibit student behaviour in educational settings (Lindroth \& Bergquist, 2010). The purpose of the current study was to examine the benefits and challenges of using laptop computers inside and outside higher education classrooms.

\section{Benefits of Using Laptops}

A review of the research focussing on the benefits of using laptop computers in higher education revealed 13 peer-reviewed articles from 2005 to 2014. A number of studies reported that students believed that laptops helped improve learning (Barak, Lipson, \& Lerman 2006; Kay \& Lauricella, 2011; Mackinnon \& Vibert, 2002; Skolnik \& Puzo, 2008; Weaver \& Nilson, 2005). Specific categories of benefits cited included research, learning activities, productivity, and communication. With respect to research, students reported improved access to academic resources during class and therefore were able to research concepts and ideas when needed (Gaudreau, Miranda, \& Gaudreau, 2014; Kay \& Lauricella, 2011; Lindroth \& Bergquist, 2010; McCreary, 2009). Regarding learning activities, a new range of laptop-based learning tasks were pursued during class including interacting with subject-specific software (Barak et al., 2006; Skolnik \& Puzo, 2008), supplementary resources (Lindroth \& Bergquist, 2010), online surveys, web-based case studies, and video podcasts (Kay \& Lauricella, 2011). With regard to productivity, students showed improved focus during class (Awwad \& Ayesh, 2013; Kay \& Lauricella, 2011, Kraushaar \& Novak, 2010), more effective note-taking (Arend, 2005; Awwad \& Ayesh, 2013; Gaudreau et al., 2014; Kay \& Lauricella, 2011; Lindroth \& Bergquist, 2010; McCreary, 2009; Skolnik \& Puzo, 2008), and better organization of files and information (Kay \& Lauricella, 2011; McCreary, 2009). Finally, with respect to communication, two benefits were observed: improved peer collaboration (Kay \& Lauricella, 2011; Kolar, Sabatini, \& Fink, 2002; Lindroth \& Bergquist, 2010; Kraushaar \& Novak, 2010; Nicol \& MacLeod, 2005) and instant messaging to peers to gain clarification of concepts presented during class (Kay \& Lauricella, 2011; Lindroth \& Bergquist, 2010; Mackinnon \& Vibert, 2002).

\section{Challenges of Using Laptops}

A review of the literature uncovered 12 articles from 2001 to 2014 reporting challenges students experienced when using laptops in higher education. Five main problem areas emerged including being distracted by other students' use of laptops, social networking, entertainment, surfing the web, and learning performance. With respect to other students' use of laptops during class, four studies noted that this was a significant distraction for students (Barak et al., 2006; Fried, 2008; Kay \& Lauricella, 2011; McCreary, 2009). One study reported no significant differences in achievement between students in laptop free vs. laptop only sections in a large lecture environment (Aguilar-Roca, Williams, \& O’Dowd, 2012). Another study noted that there were both negative and positive changes in note taking, attention, and discussions when laptop use was restricted or banned (McCreary, 2009). Regarding social networking, a number of studies reported that students distracted themselves with instant-messaging (Fried, 2008; Hembrooke \& Gay, 2003; Kay \& Lauricella, 2011; Kraushaar \& Novak, 2010; Mackinnon \& Vibert, 2002; McCreary, 2009) and personal emails (Barak et al., 2006; Fried, 2008; Gaudreau et 
al., 2014; Hembrooke \& Gay, 2003; Kay \& Lauricella, 2011; McCreary, 2009; Skolnik \& Puzo, 2008). Entertainment specific distractions included playing games (Barak et al., 2006; Fried, 2008; Hembrooke \& Gay, 2003; Kay \& Lauricella, 2011; McCreary, 2009; Skolnik \& Puzo, 2008), watching movies, podcasts, and pornography (Barak et al., 2006; Gaudreau et al., 2014; Kay \& Lauricella, 2011), listening to music (Barak et al., 2006), and surfing the web (Barak et al., 2006; Fried, 2008; Gaudreau et al., 2014; Grace-Martin \& Gay, 2001; Hembrooke \& Gay, 2003; Kay \& Lauricella, 2011; McCreary, 2009; Skolnik \& Puzo, 2008). Three papers added that increased use of laptops was negatively correlated with student performance (Fried, 2008; Hembrooke \& Gay, 2003; Kraushaar \& Novak, 2010). Finally, two studies noted that multitasking on laptops could be detrimental to learning performance (Kraushaar \& Novak, 2010; Sana, Weston, \& Cepeda, 2013).

\section{Methodological Problems}

Research on the use of laptops in higher education has provided useful information, however, at least five methodical problems compromise the integrity and clarity of the findings. First, a clear description of how laptops are used in the classroom is not offered in over half the studies (Aguilar-Roca et al., 2013; Arend, 2005; Gaudreau et al., 2014; Hembrooke \& Gay, 2003; Kolar et al., 2002; Lindroth \& Bergquist, 2010; Mackinnon \& Vibert, 2002; McCreary, 2009; Skolnik \& Puzo, 2008; Weaver \& Nilson, 2005). Benefits and challenges of using laptops could vary considerably depending on the efforts made by professors to integrate them in the classroom environment.

Second, a wide range of behaviours have been measured with respect to laptop use including class attendance (Fried, 2008; Mackinnon \& Vibert, 2002), browsing behaviour (Grace-Martin \& Gay, 2001), use of communication tools and social computing (Arend, 2005, Fired, 2008, Gaudreau et al., 2014; Hembrooke \& Gay, 2003; Kay \& Lauricella, 2011; Kraushaar \& Novak, 2010; Lindroth \& Bergquist, 2010; McCreary, 2009), collaboration (Kay \& Lauricella, 2011; Nicol \& MacLeod, 2005), use of academic resources (Arend, 2005; Kay \& Lauricella, 2011; McCreary, 2009), note taking (Aguilar-Roca et al., 2013; Arend, 2005; Fried, 2008; Gaudreau et al., 2014; Awwad \& Ayesh, 2013; Kay \& Lauricella, 2011; Lindroth \& Bergquist, 2010; McCreary, 2009), learning activities and behaviours (Kay \& Lauricella, 2011; Mackinnon \& Vibert, 2002; Skolnik \& Puzo, 2008; Weaver \& Nilson, 2005), learning performance (Aguilar-Roca et al., 2013; Kolar et al., 2002; Sana et al., 2012), and distractions such as surfing the web, games, and watching multimedia, and instant messaging (Fried, 2008; Gaudreau et al., 2014; Kay \& Lauricella, 2011; McCreary, 2009; Skolnik \& Puzo, 2008). The results from these studies, while interesting and informative, make it difficult to compare studies or assess the relative influence of potential benefits and challenges. Only one study (Kay \& Lauricella, 2011) attempted to assess a comprehensive list of potential benefits and challenges.

Third, no studies have examined the use of laptops outside the classroom. While it may seem more critical to determine the impact of laptops in the classroom, understanding how laptops are used outside the classroom is also important, particularly with respect to distractions and potential barriers to students completing academic work.

Fourth, only five of the 13 peer-reviewed studies examining laptop behaviour in higher education used a mixed methods approach to collecting and analyzing data (Hembrooke \& Gay, 2003; Kay \& Lauricella, 2011; Mackinnon \& Vibert, 2002; McCreary, 2009; Nicol \& MacLeod, 
2005). Most studies used either surveys or qualitative techniques. Because studying the use of laptops in education is a relatively new phenomenon, it is worthwhile collecting both quantitative and qualitative data to glean as much information as possible.

Finally, regardless of the data collection method used, only one study (Kay \& Lauricella, 2011) attempted to establish both the reliability and validity of evaluation tools used. Without high quality metrics, it is difficult to be confident in the results provided.

\section{Current Study}

To date, a patchwork of research findings has provided a mixed and somewhat idiosyncratic picture of laptop use in higher education classrooms and no studies have examined laptop use outside the classroom. The purpose of the current study was to investigate a comprehensive set of benefits and challenges for using laptops inside and outside higher education classrooms.

\section{Method}

\section{Overview}

To address previous methodological concerns, the following steps were taken to ensure the quality and integrity of data collected:

1. a clear description was provided about how laptops were used;

2. a comprehensive set of behaviours were assessed based on previous research;

3. benefits and challenges were assessed inside and outside the classroom;

4. both survey data and open-ended questions were used; and

5. the reliability and validity of the data collection survey was addressed.

\section{Participants}

The sample was comprised of 156 university students (54 males, 102 females) in the first $(n=40)$, second $(n=63)$, third $(n=3)$ or fourth year $(n=50)$ of their studies. Students were enrolled in either communication $(n=107)$ or teacher education $(n=49)$ courses while using their laptops. The average self-reported grade was 81.4 percent (S.D. $=6.3$, range 45 to 90 ). The majority of students claimed they were either very interested $(n=62,40 \%)$ or interested $(n=75,48 \%)$ in the course they were taking when using the laptop computer. Most students reported being very comfortable $(n=93,60 \%)$ or comfortable $(n=52,33 \%)$ with using computers. All students leased an IBM laptop from the university and had wireless access to the web throughout the campus.

\section{Teaching Strategies Implemented}

The predominate teaching strategy observed in previous laptop-based studies was a lecture format, with a PowerPoint presentation and students taking notes (e.g., Awwad \& Ayesh, 2013; Demb et al., 2004; Fried, 2008; Grace-Martin \& Gay, 2001; Hembrooke \& Gay, 2003; Kraushaar \& Novak, 2010; Lindroth \& Bergquist, 2010; Sana et al., 2012; Wurst, Smarkola, \& Gaffney, 2008). In the current study, a wide variety of teaching methods were used. In some classes, where the learning goal was to disseminate certain concepts, a standard lecture with a PowerPoint presentation was used. However, a number of interactive strategies were also 
employed that required more active use of laptops including web searches for specific topics, online case studies, assessment of video podcasts, reviewing published articles, participating in online voting and surveys, working with learning objects, sharing and coordinating ideas using common discussion boards, creating presentations and learning materials with tool-based software, using subject-specific software, creating mind-maps, and reviewing course materials posted on the class website.

\section{Procedure}

During the final class meeting, students were invited to participate in an anonymous, online survey. Participation was voluntary, and the instructor, who left the class while the survey was being completed, was unable to determine who chose to participate. The data was not accessed until all marks for the courses were submitted. It took about 10-15 minutes for students to complete the survey.

\section{Data Sources}

Descriptive data. Students were asked to provide their gender, year of study, course taken, and estimated grade in the course in which they were enrolled. They also rated their interest in the course they were taking and their computer comfort level (Appendix A - Questions 1 to 6).

Student laptop use survey. Based on a compilation of laptop behaviours targeted in previous studies (Aguilar-Roca et al., 2013; Arend, 2005; Fried, 2008; Gaudreau et al., 2014; Awwad \& Ayesh, 2013; Lindroth \& Bergquist, 2010; McCreary, 2009; Skolnik \& Puzo, 2008) and the laptop scale research of Lauricella \& Kay (2010), an expanded version of the Student Laptop Use Survey was employed to assess use of laptops inside and outside of the classroom.

Benefits (referred to as academic use in the survey) of using laptops inside the classroom (Appendix A, items 8a to 8h) included active use (searching the web, using interactive tools, participating in online surveys, communicating with peers, using academic software) and passive use (taking notes, using instructor notes, following a PowerPoint presentation on the laptop). Active use refers to students engaging in activities to find information or construct new knowledge and is based on a constructivist perceptive of learning (e.g., Bruner, 1960; Vygotsky, 1978). Passive use refers to students listening to and recording information and is aligned with an associationist perspective (e.g., Gagné, 1985).

Benefits (referred to as academic use in the survey) outside the classroom (Appendix A, items $12 \mathrm{a}$ to $12 \mathrm{~h}$ ) were evaluated by asking students about productivity (organize notes and materials, online interaction, and using software for academic purposes), collaboration (sharing notes and materials, communicating with peers for academic purposes, working with peers, getting help form peers), and research (search the web for academic purposes, searching the university library). Note that these categories were derived from previous research studies, a preliminary survey about laptop behaviours outside class (Lauricella \& Kay, 2010), and recommendations from two experienced instructors.

Challenges (referred to as non-academic use in the survey) of using laptops inside (Appendix A, items 10a to 10h) and outside the classroom (Appendix A, items 14a to 14h) were assessed based on three categories: information search (searching the web for personal reasons), entertainment (playing games, watching moves, watching short video clips), and social 
networking (Facebook, Twitter, instant messaging, email). These categories were derived from previous research.

Acceptable internal reliability based on Cronbach's alpha, construct validity, content validity, and convergent reliability estimates for the scale in this study were originally established by Lauricella \& Kay (2010).

Student comments. Students were asked the following open-ended questions about benefits and challenges of using laptops inside and outside of class:

1. Overall what are the biggest benefits to having a laptop IN class for this course? Why?

2. Overall what are the biggest distractions in having a laptop IN class for this course? Why?

3. Overall what are the biggest benefits to having a laptop OUTSIDE class? Why?

4. Overall what are the biggest distractions to having a laptop OUTSIDE class? Why?

All responses were categorized based on the scoring scheme developed by Kay \& Lauricella (2011). Comments were categorized using an inductive approach outlined by Miles \& Huberman (1994). Once the categories were identified, inter-rater reliability estimates from $96 \%$ to $98 \%$ were observed. Categories used to assess comments are presented in table 2 (benefits inside class), table 4 (distractions inside class), table 6 (benefits outside class), and table 8 (distractions outside class).

\section{Research Questions}

Four main research questions were addressed in this study:

1. What are benefits of using a laptop in higher education classrooms?

2. What are challenges of using a laptop in higher education classrooms?

3. What are benefits of using a laptop outside higher education classrooms?

4. What are challenges of using a laptop outside higher education classrooms?

\section{Results}

\section{Frequency of Laptop Use}

On average, students reported using their laptops 7.9 hours per day $(S . D .=3.8$; range 1 to $24)$ inside and outside of classroom. The majority of students noted that they used laptop computers five $(n=20,13 \%)$, six $(n=25,16 \%)$, eight $(n=24,16 \%)$, or 10 hours $(n=24,16 \%)$ per day.

\section{Benefits of Using Laptops in the Classroom}

Survey data. With respect to passive use of laptops, over $90 \%$ of the students followed and added comments to the notes or PowerPoint presentations provided by the professor sometimes or frequently. Two thirds of the students used their laptops to take notes independent from lecture materials provided sometimes or frequently. Regarding active use of laptops, over $90 \%$ of the students used academic software or searched the web for academic purposes 
sometimes or frequently. Over three-quarters of the students collaborated with their peers (e.g., email, instant messaging) or used online interactive tools for academic support sometimes or frequently. Finally, just under two thirds of students noted that they filled in online surveys related to the class sometimes or frequently. A summary of in-class benefits is presented in Table 1 .

Table 1:

\begin{tabular}{|c|c|c|c|c|}
\hline Variable & $M(S D)$ & $\begin{array}{l}\text { Never/ } \\
\text { Rarely }\end{array}$ & Sometimes & $\begin{array}{l}\text { Frequently / } \\
\text { Very Frequently }\end{array}$ \\
\hline \multicolumn{5}{|l|}{ Passive Use } \\
\hline Use Professors Notes & $4.0(0.9)$ & $6 \%$ & $20 \%$ & $74 \%$ \\
\hline Follow PowerPoint Pres. & $3.8(1.2)$ & $15 \%$ & $14 \%$ & $71 \%$ \\
\hline Take Laptop Notes & $3.2(1.3)$ & $31 \%$ & $24 \%$ & $44 \%$ \\
\hline \multicolumn{5}{|l|}{ Active Use } \\
\hline Web-Based Research & $3.7(0.9)$ & $9 \%$ & $28 \%$ & $63 \%$ \\
\hline Academic Software Use & $4.2(1.0)$ & $6 \%$ & $10 \%$ & $84 \%$ \\
\hline Online Interactive & $3.3(1.0)$ & $16 \%$ & $42 \%$ & $42 \%$ \\
\hline \multicolumn{5}{|l|}{ Tools } \\
\hline Online Surveys & $2.9(1.1)$ & $39 \%$ & $32 \%$ & $29 \%$ \\
\hline Collaboration & $3.5(1.3)$ & $23 \%$ & $22 \%$ & $54 \%$ \\
\hline
\end{tabular}

Open-ended question. Students offered 175 comments about the benefits of passive $(n=84)$ and active $(n=91)$ use of laptops computers. In terms of passive use, students took notes $(n=53)$ or followed a PowerPoint presentation $(n=31)$. A number of students combined these two activities when they added supplementary notes to a PowerPoint presentation the instructor posted prior to class. See table 2 for sample quotes about beneficial passive use of laptops.

Active use of laptops included accessing resources $(n=51)$, specific laptop-based activities $(n=24)$, and collaboration with peers $(n=16)$. With respect to accessing resources, students searched for direct references to information or concepts brought up in class $(n=24)$, general information $(n=23)$, or course materials $(n=4)$. Regarding specific laptop activities, students interacted with online tools and software $(n=12)$, edited their peers' work $(n=5)$, participated in online quizzes to check for understanding $(n=5)$, and produced class materials $(n=2)$. Finally, when using the laptop as a collaborative tool, students emailed or messaged their peers for questions, clarity, or missed information during a lecture, often because they did not want to disrupt the flow of the class $(n=16)$. See table 2 for sample quotes about beneficial active use of laptops.

It is worthwhile noting that nine students reported that laptops were not used in the class or prohibited during certain times in a lecture. 
Table 2:

In-Class Benefits of Using Laptops - Sample Comments $(n=175)$

\begin{tabular}{|c|c|}
\hline & Sample Comments \\
\hline \multicolumn{2}{|l|}{$\begin{array}{l}\text { Category } \\
\text { Passive Use }\end{array}$} \\
\hline $\begin{array}{l}\text { Taking Notes } \\
(\mathrm{n}=53 ; 30 \%)\end{array}$ & $\begin{array}{l}\text { "I think they benefit us when it comes to note-taking because it } \\
\text { makes it easy to take down information and add additional } \\
\text { thoughts when your hand isn't cramped." } \\
\text { "Taking notes in the PowerPoint is very useful." } \\
\text { "It makes it easier to take notes, because otherwise I would be } \\
\text { hand writing notes and eventually re-writing them on the } \\
\text { computer anyways." }\end{array}$ \\
\hline $\begin{array}{l}\text { Following PowerPoint } \\
(\mathrm{n}=31 ; 18 \%)\end{array}$ & $\begin{array}{l}\text { "I was able to follow the PowerPoint slides during class." } \\
\text { "Following a professors PowerPoint slides online while they } \\
\text { speak allows lectures to run more smoothly and quickly." } \\
\text { "Being able to follow the lecture on my laptop - because } \\
\text { sometimes it's hard to see the white board." }\end{array}$ \\
\hline $\begin{array}{l}\text { Active Use } \\
\quad \text { Research } \\
(\mathrm{n}=51 ; 29 \%)\end{array}$ & $\begin{array}{l}\text { "The laptop] can be used for online readings, accessing the } \\
\text { course content in WebCT and get the information for the } \\
\text { current class." } \\
\text { "Also useful to refer to what the professor is talking about just } \\
\text { in case there is confusion (i.e., Googling a point the prof } \\
\text { noted)." } \\
\text { "I also like having instant access to online resources during } \\
\text { class time, as well as having documents which are instantly } \\
\text { searchable, which isn't possible with a hard-copy document." }\end{array}$ \\
\hline $\begin{array}{l}\text { Learning Activities } \\
(\mathrm{n}=24,14 \%)\end{array}$ & $\begin{array}{l}\text { "The laptop is helpful for] using very interesting tools, such as } \\
\text { PowerPoint, Camtasia, clicker programs, and One-note." } \\
\text { "To explore the manipulatives and interactive tools." } \\
\text { "Able to use our laptops to edit each others work - makes it } \\
\text { easier to access work and edit without having to ruin my peer's } \\
\text { essay." } \\
\text { "I can quickly create PowerPoint or other displays that will } \\
\text { enhance a mini-lesson exercise." }\end{array}$ \\
\hline $\begin{array}{l}\text { Collaboration } \\
(\mathrm{n}=16,9 \%)\end{array}$ & $\begin{array}{l}\text { "It also helps with communicating with colleagues if you } \\
\text { missed a point the teacher was saying or something." } \\
\text { "I message friends questions about the lecture for clarification } \\
\text { rather [than] interrupting the flow of class." }\end{array}$ \\
\hline
\end{tabular}




\section{Challenges of Using Laptops in the Classroom}

Survey data. Challenges or distractions that students experienced during class were organized into three categories: information searching, social networking, and entertainment. Almost three quarters of the students searched the web for personal information during class sometimes or frequently. Regarding social networking, instant messaging was the most common activity, followed by sending personal emails, and checking Facebook. Between 60 and 75\% of students used these tools sometimes or frequently during class. Twitter was consulted rarely, with only $6 \%$ of the students using it sometimes or frequently during class. Finally, with respect to entertainment, about $20 \%$ of the students played games or watched video podcasts sometimes or frequently during class. Only $8 \%$ of the students watched movies. A summary of in-class challenges is presented in Table 3 .

Table 3:

In Class Distractions Using Laptops $(n=156)$

\begin{tabular}{|c|c|c|c|c|}
\hline Variable & $M(S D)$ & $\begin{array}{l}\text { Never/ } \\
\text { Rarely }\end{array}$ & Sometimes & $\begin{array}{l}\text { Frequently/ } \\
\text { Very Frequently }\end{array}$ \\
\hline \multicolumn{5}{|l|}{ Information Search } \\
\hline Personal Web Search & $3.1(1.2)$ & $27 \%$ & $33 \%$ & $40 \%$ \\
\hline \multicolumn{5}{|l|}{ Social Networking } \\
\hline Personal & $3.1(1.4)$ & $36 \%$ & $16 \%$ & $48 \%$ \\
\hline \multicolumn{5}{|l|}{ Instant Messaging } \\
\hline Personal Email & $2.9(1.3)$ & $40 \%$ & $24 \%$ & $35 \%$ \\
\hline Facebook & $2.9(1.4)$ & $40 \%$ & $21 \%$ & $40 \%$ \\
\hline Use Twitter & $1.2(0.7)$ & $94 \%$ & $3 \%$ & $3 \%$ \\
\hline \multicolumn{5}{|l|}{ Entertainment } \\
\hline Play Games & $1.8(1.1)$ & $80 \%$ & $11 \%$ & $10 \%$ \\
\hline Watch Podcasts & $1.8(1.1)$ & $80 \%$ & $10 \%$ & $10 \%$ \\
\hline Watch Movies & $1.3(0.8)$ & $92 \%$ & $5 \%$ & $3 \%$ \\
\hline
\end{tabular}

Open-ended question. Students offered 123 comments about the challenges of using laptop computers in the classroom. The biggest challenge involved social networking with almost two thirds of the students reporting being distracted by Facebook $(n=42)$, instant messaging $(n=27)$, or email $(n=10)$. Twelve percent of the students noted they were enticed by various entertainment distractions such as surfing the web $(n=10)$, playing games $(n=4)$ or listening to music $(\mathrm{n}=2)$. An additional $10 \%$ of the students were distracted by other students' use of laptops during class $(n=11)$ and $10 \%$ of students $(n=12)$ claimed that the laptop was a distraction, but were non-specific about the source. Finally, several students $(n=5)$ noted that they were distracted because of trying to finish assignments that were due for other classes. It is important to note that 30 students, when asked about the challenges that laptops posed for them, reported that there were no problems or distractions. See table 4 for sample comments from students about each of the challenge categories noted. 
Table 4:

In-Class Challenges of Using Laptops - Sample Comments ( $n=153)$

\begin{tabular}{|c|c|}
\hline Category & Sample Comments \\
\hline $\begin{array}{l}\text { Social Networking } \\
\quad(n=79 ; 64 \%)\end{array}$ & $\begin{array}{l}\text { "Facebook is a big distraction because it is so easy to open } \\
\text { and close. It's something to do when the lecture gets boring } \\
\text { or I want to communicate with others." } \\
\text { "E-mail checking. I like to keep up to date on things going } \\
\text { on outside of class." } \\
\text { "MSN is personally my biggest distraction because it is so } \\
\text { easy to just get distracted talking to your friends because it is } \\
\text { so easily accessible." } \\
\text { "Instant messaging and social networking sites such as } \\
\text { Facebook serve as a big factor in the distraction. This is } \\
\text { because everyone feels the need to be in touch with their } \\
\text { peers ... it doesn't fit well into the classroom atmosphere }\end{array}$ \\
\hline $\begin{array}{l}\text { Entertainment } \\
(\mathrm{n}=15,12 \%)\end{array}$ & $\begin{array}{l}\text { "It provides instant access to the internet which can just as } \\
\text { easily be used for personal/non-academic reasons as it can be } \\
\text { for academic ones." } \\
\text { "Games, because I have a bunch on my computer and they } \\
\text { tend to distract me." }\end{array}$ \\
\hline $\begin{array}{l}\text { Other Students } \\
(\mathrm{n}=12,10 \%)\end{array}$ & $\begin{array}{l}\text { "The incessant beeping noise that happens every time people } \\
\text { open and close their laptops." } \\
\text { "It is hard to concentrate on what the instructor is saying } \\
\text { when the people around you are playing games, listening to } \\
\text { music and chatting online." }\end{array}$ \\
\hline $\begin{array}{l}\text { General } \\
(\mathrm{n}=12,10 \%)\end{array}$ & $\begin{array}{l}\text { "This is class is sort of boring anyways. The laptop provides } \\
\text { something to do. It also gives me a break helping me focus } \\
\text { better when I do try paying attention." } \\
\text { "If you get bored, it is easy to drift your focus and go to } \\
\text { something more interesting within the computer." }\end{array}$ \\
\hline $\begin{array}{l}\text { Course Work } \\
(n=5,4 \%)\end{array}$ & $\begin{array}{l}\text { "Working on other course assignments, because laptop is out } \\
\text { and a chance to maximize time by multitasking arises." } \\
\text { "I begin to work on other assignments for other classes." }\end{array}$ \\
\hline $\begin{array}{l}\text { No Distractions } \\
(\mathrm{n}=30)\end{array}$ & $\begin{array}{l}\text { "In this class I find that I am compelled to pay attention. It's } \\
\text { so interesting, that there isn't time to play games or do } \\
\text { anything not pertaining to the course." } \\
\text { "[This] class is very interesting and has good discussions so I } \\
\text { seldom feel the need to use these tools during her class." } \\
\text { "The class is involved enough to keep me from wanting to be } \\
\text { distracted by these other options" }\end{array}$ \\
\hline
\end{tabular}

\section{Benefits of Using Laptops Outside the Classroom}

Survey data. Benefits of using laptops outside of the classroom included productivity, research and collaboration. With respect to productivity, almost all students used academic software or organized course materials outside of class sometimes or frequently. Three quarters 
of the students used online interactive tools sometimes or frequently outside of class. Concerning research, over $95 \%$ of the students conducted academic web searches and over $70 \%$ searched library databases sometimes or frequently outside of class. Finally, regarding collaboration, 83 to $87 \%$ of students used laptops to communicate with peers, complete group work, and share notes or resources sometimes or frequently outside of class. A summary of benefits when using laptops outside of class is presented in Table 5.

Table 5:

Outside Class Benefits Using Laptops (Survey Data)

\begin{tabular}{|c|c|c|c|c|}
\hline Variable & $M(S D)$ & $\begin{array}{l}\text { Never/ } \\
\text { Rarely }\end{array}$ & Sometimes & $\begin{array}{l}\text { Frequently/ } \\
\text { Very Frequently }\end{array}$ \\
\hline \multicolumn{5}{|l|}{ Productivity } \\
\hline Academic Software Use & $4.3(0.8)$ & $4 \%$ & $7 \%$ & $89 \%$ \\
\hline Org. Course Materials & $3.6(0.9)$ & $9 \%$ & $34 \%$ & $57 \%$ \\
\hline Online Interactive Tools & $3.1(1.0)$ & $26 \%$ & $37 \%$ & $37 \%$ \\
\hline \multicolumn{5}{|l|}{ Research } \\
\hline Academic Web Search & $3.9(0.8)$ & $4 \%$ & $22 \%$ & $74 \%$ \\
\hline Search Library Databases & $3.0(1.0)$ & $29 \%$ & $39 \%$ & $32 \%$ \\
\hline \multicolumn{5}{|l|}{ Collaboration } \\
\hline Acad. Com. with Peers & $3.8(1.0)$ & $12 \%$ & $22 \%$ & $65 \%$ \\
\hline Group work & $3.7(1.0)$ & $13 \%$ & $24 \%$ & $63 \%$ \\
\hline Share Notes and Resources & $3.6(1.0)$ & $17 \%$ & $25 \%$ & $58 \%$ \\
\hline
\end{tabular}

Open-ended question. Students commented 155 times about the benefits of using laptops outside the classroom. The most noted benefit was research-related $(n=66)$ and involved being able to access a wide variety of resources including course and assignment information $(\mathrm{n}=18)$, files created for class $(n=17)$, research information $(n=10)$, and web-based resources $(n=5)$. Other noteworthy benefits outside the classroom included collaboration with peers and communication with professors and tutors $(n=40)$, the flexibility to do work when and where they wanted $(n=22)$, producing work such as assignments, homework, and notes $(\mathrm{n}=17)$, and being better organized $(n=10)$. See table 6 for sample comments from students about each category of benefits for using laptops outside of the classroom.

Table 6:

Outside Class Benefits of Using Laptops - Sample Comments $(n=155)$

\begin{tabular}{ll}
\hline Category & Sample Comments \\
\hline Research & "[I liked] being able to access information from home that relates to lectures." \\
& "Having a laptop outside of school allows for an easier process when \\
& researching for assignments." \\
& "The biggest benefit to having a laptop out of class is that you can find \\
& information for classes anywhere." \\
& "Having a laptop outside of class allows for easy access of files where ever we \\
& happen to be." \\
& "I can have access to the school library outside of class."
\end{tabular}




\begin{tabular}{|c|c|}
\hline $\begin{array}{l}\text { Collaboration } \\
\qquad(\mathrm{n}=40,24 \%)\end{array}$ & $\begin{array}{l}\text { "Being able to quickly network with classmates when working on projects is } \\
\text { great." } \\
\text { "We share resources, help each other, generate different ideas and we are } \\
\text { constantly reminding one another of the different assignments we have." } \\
\text { "To stay connected to the teacher to ask questions and clarify material." }\end{array}$ \\
\hline $\begin{array}{l}\text { Flexibility } \\
(n=22,13 \%)\end{array}$ & $\begin{array}{l}\text { "[I like] being able to do mobile computing, wherever you want whenever you } \\
\text { want." } \\
\text { "It's helpful because you can work on homework anywhere and when there is } \\
\text { down time you can be productive." } \\
\text { "The biggest benefit to having a laptop out of class is that you can find } \\
\text { information for classes anywhere. You don't have to be in class or at the } \\
\text { school to do assignments." }\end{array}$ \\
\hline $\begin{array}{l}\text { Productivity } \\
(\mathrm{n}=17,17 \%)\end{array}$ & $\begin{array}{l}\text { "[I like being able to] take notes after class or working on school assignments. } \\
\text { "To be able to do homework quickly, and not have to worry about waiting to } \\
\text { share a family computer." } \\
\text { "It makes it easier to do my school work and have the internet at my fingertips } \\
\text { for research." }\end{array}$ \\
\hline $\begin{array}{l}\text { Organization } \\
(\mathrm{n}=10 ; 6 \%)\end{array}$ & $\begin{array}{l}\text { "I think we all have computers at home but the benefit of having the same } \\
\text { laptop at school and at home lets us easily access what we did at school and } \\
\text { organize our notes for the next class." } \\
\text { "All the programs and assignments are accessible wherever you're working } \\
\text { and you don't have to carry a bunch of books and papers. }\end{array}$ \\
\hline
\end{tabular}

\section{Challenges of Using Laptops Outside the Classroom}

Survey data. Three key challenges or distractions of using laptops outside the classroom included information searches, social networking, and entertainment. Almost every student engaged in web searches for personal reasons sometimes or frequently outside of class. Social networking outside of class was also a popular distraction with 85 to 96 percent of students using personal email, Facebook, and instant messaging sometimes or frequently. Between 70 and 83 percent of the students entertained themselves outside of class by watching movies or video podcasts sometimes or very frequently. Finally, six out of 10 students played games sometimes or very frequently outside of class. A summary of challenges when using laptops outside of class is presented in Table 7. 
Table 7:

Outside Class Distractions Using Laptops $(n=156)$

\begin{tabular}{|c|c|c|c|c|}
\hline Variable & $M(S D)$ & $\begin{array}{l}\text { Never/ } \\
\text { Rarely }\end{array}$ & Sometimes & $\begin{array}{l}\text { Frequently/ } \\
\text { Very Frequently }\end{array}$ \\
\hline \multicolumn{5}{|l|}{ Information Search } \\
\hline Personal Web Search & $4.4(0.8)$ & $3 \%$ & $11 \%$ & $87 \%$ \\
\hline \multicolumn{5}{|l|}{ Social Networking } \\
\hline Personal Email & $4.2(0.9)$ & $4 \%$ & $19 \%$ & $77 \%$ \\
\hline Facebook & $4.0(1.2)$ & $12 \%$ & $15 \%$ & $73 \%$ \\
\hline Personal & $4.0(1.3)$ & $14 \%$ & $15 \%$ & $71 \%$ \\
\hline \multicolumn{5}{|l|}{ Instant Messaging } \\
\hline Use Twitter & $1.6(1.2)$ & $84 \%$ & $4 \%$ & $12 \%$ \\
\hline \multicolumn{5}{|l|}{ Entertainment } \\
\hline Watch Podcasts & $3.6(1.2)$ & $18 \%$ & $25 \%$ & $58 \%$ \\
\hline Watch Movies & $3.2(1.3)$ & $30 \%$ & $27 \%$ & $43 \%$ \\
\hline Play Games & $2.8(1.3)$ & $39 \%$ & $27 \%$ & $34 \%$ \\
\hline
\end{tabular}

Open-ended question. Students provided 111 comments about challenges they experienced while using laptops outside the classroom. The two main challenges were communication $(n=54)$ and entertainment based $(n=42)$. With respect to communication, students found themselves using an array of tools to socialize with friends including Facebook $(n=22)$, instant messaging $(n=16)$, email $(n=7)$, Skype $(n=2)$, and Twitter $(n=1)$. Regarding entertainment, watching videos, movies or TV was the biggest distraction $(n=19)$, followed by playing games $(n=11)$, and surfing the web $(n=10)$. Fifteen students made general, non-specific comments about laptops being a distraction at times.

Note that 26 students commented that laptops were not a distraction outside of the classroom or that they used them appropriately when needed. See table 8 for sample comments about student distractions outside of class. 
Table 8:

Outside Class Challenges of Using Laptops - Sample Comments $(n=111)$

\begin{tabular}{|c|c|}
\hline Category & Sample Comments \\
\hline $\begin{array}{l}\text { Social Networking } \\
\quad(\mathrm{n}=54 ; 49 \%)\end{array}$ & $\begin{array}{l}\text { "Sometimes if I am feeling stressed or overwhelmed on a school } \\
\text { related task, I will check my email quickly just to have a change of } \\
\text { scenery." } \\
\text { "As everyone says, Facebook is the number one procrastinating } \\
\text { device." } \\
\text { "[It is] hard with instant messaging, Facebook, email, all of these } \\
\text { tools are used for both academic and person reason, making it hard } \\
\text { to defeat the temptation in researching something more interesting } \\
\text { to the student." } \\
\text { "I will set time aside for homework but then take a break to watch a } \\
\text { movie or download music or go on Facebook. So it feels like I've } \\
\text { been working on my homework for } 3 \text { hours when in reality I've } \\
\text { only done about an hour's work." } \\
\text { "When I am working on a tough assignment or am procrastinating } \\
\text { getting things done I often find myself going on Facebook or } \\
\text { twitter." }\end{array}$ \\
\hline $\begin{array}{l}\text { Entertainment } \\
(\mathrm{n}=42,38 \%)\end{array}$ & $\begin{array}{l}\text { "Outside of the classroom, I find I'm quite easily distracted, } \\
\text { generally by hopping on assorted games (particularly the short time } \\
\text { wasters i.e. Solitaire) or doing random web browsing when I should } \\
\text { be working." } \\
\text { "Movies are a big distraction for me because I know almost every } \\
\text { movie made is somewhere online." } \\
\text { "I don't have to change the tool I'm interfacing with in order to } \\
\text { access distractions (i.e., games and videos)." } \\
\text { "Having access to the laptop outside of class can be distracting if } \\
\text { there is school work that needs to be done, but instead one winds up } \\
\text { playing video games or watching YouTube all night." }\end{array}$ \\
\hline $\begin{array}{l}\text { General } \\
(n=15,14 \%)\end{array}$ & $\begin{array}{l}\text { "I do not stay on track with my school work." } \\
\text { "If I'm not focused, it aids in procrastination." } \\
\text { "Sometimes I find myself distracted doing personal things other } \\
\text { than staying to my work." }\end{array}$ \\
\hline
\end{tabular}

\section{Discussion}

The purpose of this study was to examine benefits and challenges of using laptops inside and outside higher education classrooms. A concerted effort was made to collect high quality data by noting how laptops were used, providing a clear description of the sample, and assessing a wide range of behaviours using both survey and open-ended questions. A key advantage in the current study is that a wide range of laptop behaviours were assessed, making it possible to compare the relative frequency of benefits and challenges. The majority of previous studies focussed on isolated and somewhat idiosyncratic components. 


\section{Laptop Use in the Classroom}

Benefits. Students engaged in both passive and active use of laptop computers during class. This type of distinction has not been noted in previous research, perhaps because of the restricted range of laptop activities used in higher education classrooms. In the current study a variety of tools and activities were integrated into the classroom.

The most popular passive activity was note taking and this result is consistent with previous research (Arend, 2005; Kay \& Lauricella, 2011; Lindroth \& Bergquist, 2010; Skolnik \& Puzo, 2008). However, the current study fleshed out three types of note taking, two of which were more popular than the third. Students preferred to follow and augment notes or PowerPoint presentations provided by the instructor as opposed to simply taking notes on their own. It is possible that starting out with a core set of notes reduces the cognitive load of students and allows them to focus on understanding the material presented. Further research is needed to explore this speculation.

Quantitative and qualitative data suggested that beneficial active use of computers in the classroom could be organized according to three kinds of activities: research, learning-focussed, and collaboration. Research activities focussed on searching for course materials, supplementing concepts presented in class, and checking secondary sources. These results are consistent with previous studies (Kay \& Lauricella, 2011; Lindroth \& Bergquist, 2010), although descriptions of the actual research activities of students are more detailed in this study. Learning focussedactivities included use of subject-specific software, online interactive tools, and online surveys. Again, the results coincide with previous research findings (e.g., Barak et al., 2006; Kay \& Lauricella, 2011; Skolnik \& Puzo, 2008). Finally, collaborative learning occurred with peers particularly when students had questions about concepts presented. This result was mirrored by a number of prior studies (e.g., Kay \& Lauricella, 2011; Kolar, Sabatini, \& Fink, 2002; Lindroth \& Bergquist, 2010; Nicol \& MacLeod, 2005).

Note that with respect to beneficial activities, learning tasks in the classroom, webresearch, and the use of academic software were used most frequently, followed by online tools and collaboration. Online surveys were used relatively infrequently. These findings may reflect the frequency in which instructors chose to use these activities in the class. It is not clear at this stage how effective each of these tools were or whether they reflect student preferences.

Challenges. The most frequent in-class distraction, exhibited by nearly three quarters of all students, was searching the web for non-academic or personal information. This result has been reported previously (e.g., Barak et al., 2006; Fried, 2008; Grace-Martin \& Gay, 2001; Hembrooke \& Gay, 2003; Kay \& Lauricella, 2011; Skolnik \& Puzo, 2008), however, the prevalence and relative frequency of web searching behaviour in the classroom had not been recorded.

Social networking occurred almost as frequently as surfing the web with six out of every ten students contacting peers for social reasons by using instant messaging, email, and Facebook. Both instant messaging and email have been noted in previous research (e.g., Fried, 2008; Hembrooke \& Gay, 2003; Kay \& Lauricella, 2011; Mackinnon \& Vibert, 2002), but again the frequency of use compared to other distractions had not been examined. The use of Facebook is new in the literature as a distraction. A number of students noted that ease of use made all three 
of these social networking tools particularly seductive with respect to diverting their attention. If a student's attention or engagement wanes, the beneficial aspects of using a laptop in the classroom can quickly and almost seamlessly transition into distractive behaviours. This phenomenon may explain why some instructors may prohibit or try to limit the use of laptops in higher education classrooms (e.g., McCreary, 2009; McWilliams, 2005; Schwartz, 2003; Young, 2006).

The third category of distraction, entertainment, was experienced relatively infrequently with only $10 \%$ of the students playing games or watching video podcasts during class frequently. Two previous studies also reported that these diversions were relatively uncommon (Barak et al., 2006; Kay \& Lauricella, 2011).

Benefits vs. challenges. According to the survey data, beneficial activities with laptops in the classroom were reported, on average, $30 \%$ more often than distractions. Ultimately, the benefits and challenges of using laptops in class may be partially dependent on how engaging the class is. As one student commented:

"I would say that the biggest distraction is also the reason why the laptop is a learning tool. It provides instant access to the internet which can just as easily be used for personal/non academic reasons as it can be for academic ones. However, I often find that if the class is interesting enough I won't use my laptop for leisure/personal activities, but instead participate in what is going on in the class."

A concerted effort was made by the instructors in this study to use laptops in meaningful ways. Therefore it would be anticipated that the benefits would outweigh the distractions. However, if laptops were used more passively and less effectively, it is expected that computerrelated distractions would increase. It is speculated, then, that the ratio of benefits to distractions is dependent on the effectiveness of pedagogical strategies employed as well as student cognitive engagement. Further research is needed to test this speculation.

Note that on some occasions, students were explicitly told not to use their laptops, perhaps in an effort to limit potential distractions. If an instructor does not plan for the meaningful use of laptops in the classroom, restricting use may be a sensible solution given that students clearly seek distractions. On the other hand, given the range of potentially effective laptop activities used in the current study, preventing students from using laptops could inhibit motivation and learning.

\section{Laptop Use Outside the Classroom}

Benefits. In this study, three major benefits of using laptops outside the classroom were supported by survey data and open-ended questions: research on the web, collaboration with peers, and productivity using the laptop software and web-based tools. The frequency of these activities was high, often ranging from 80 to $95 \%$. While no formal research has been conducted on how students use laptops outside the higher classroom for academic purposes, the results support Tapscott's (2008) description of today's "net generation" and their pervasive use of technology in general. Of course these benefits are not exclusive to having a laptop and could just as easily be achieved with a desktop computer. However, some open-ended responses 
indicated that students enjoyed the flexibility of doing work when and where they want, a finding that was predicted by both McCrea (2010) and Tapscott (2008).

Challenges. Three major distractions were reported regarding student use of laptops outside the classroom and included searching the web for personal reasons, social networking with a variety of tools, and entertainment in the form of watching videos and/or playing games. These distractions played a prominent role in student life outside the classroom with almost universal participation in activities such as surfing the web, sending emails, using Facebook, or watching video podcasts. Tapscott (2008) noted that technology is used in all facets of the "net generation" and the result of the current study supports this claim.

Benefits vs. Challenges. According to the survey data, beneficial behaviours with laptops outside the class are similar to the challenging behaviours in terms of frequency, unlike inside the classroom where benefits were more frequent. This result is to be expected given that the cultural norm inside a classroom is to learn and work, whereas outside the classroom there is more accepted variance in behaviour. One would expect more distractions outside the classroom because, of course, a student's life is not devoted entirely to academics. However, because the same tool, namely the laptop, is being used for both work and pleasure, the temptation of distraction may be higher. As one student remarked:

"Having access to the laptop outside of class can be distracting [even] if there is school work that needs to be done ... instead one winds up playing video games or watching YouTube all night."

The critical question is to what extent distractions interfere with academic work. Procrastination is a well known phenomenon (e.g., Andreou, 2007; Claessens, van Eerde, Rutte, \& Roe, 2007), although the extent to which laptops facilitate and encourage avoidance of work in unknown. In the current study, the results suggest that laptops play an integral and frequent role in social interactions and entertainment outside the classroom. More research needs to be conducted on the extent to which laptops outside the classroom influence academic productivity and success.

\section{Educational Implications}

Several suggestions arise from the results of the current study for instructors who wish to maximize the benefits of using laptops inside the classroom. First, providing notes and/or PowerPoint presentations ahead of class encourages more students to participate in the note taking process. It is possible that cognitive load is reduced and students can concentrate more on concepts being presented, although this has yet to be confirmed. Second, students readily participate in planned activities with subject-specific software, online learning tools and online surveys. Third, while students get distracted with activities such as surfing the web and social networking, they also use the same tools to search for a wide range of academic resources, communicate with peers, and share resources. When instructors plan for a wide range of meaningful laptop activities, beyond the traditional passive PowerPoint presentation, the benefits of using laptops appear to exceed the distractions.

\section{Limitations and Future Research}

In this study, the quality of data was enhanced by addressing methodological limitations of previous research. Noting how laptops were used, providing a clear description of the sample, 
assessing a wide range of behaviours, using a reliable and valid survey, and a mixed methods approach helped maximize the impact of information collected and should probably be employed in future research. Nonetheless, several limitations are worth noting to improve and guide future research efforts. First, while the sample size was moderately large, a more diverse set of subject areas and instructors would be a next step in building confidence in the results. The larger sample could be used to determine if there are differences in laptops behaviours among subject areas.

Second, the current study enumerated a wide range of benefits and challenges, but did not examine the interaction between the two, nor did it address the relationship between laptop behaviours inside and outside of class. Focus groups, case study, interview, and/or observational data would helpful in examining the extent to which distractions interfere with learning inside and outside the classroom. In addition, detailed qualitative data might be helpful in discovering when students shift from beneficial laptop activities to more distracting endeavours. Third, it would be beneficial to match the specific teaching strategies used by an instructor with the specific laptop behaviours that occur during a class. This approach, perhaps supported by the use of interviews and/or tracking software, could provide useful data on how pedagogy influences what students do with their laptops. In addition, a more detailed analysis of the instructor's perspective could offer valuable insights into laptop behaviour. Fourth, while laptops are still the primary mobile device purchased by higher education students, it might be informative to broaden the scope of this research to the use of other mobile devices such as smartphones or tablets. Fifth, $93 \%$ of the participants in this study were comfortable using computers, $88 \%$ enjoyed the subject being taught, and the average grade reported was $81 \%$. This positive scenario clearly is not representative of all higher education classrooms. It would worthwhile investigating individual differences among students with respect to laptop use. Not all students are the same and there might be differences with respect to gender, computer experiences, academic ability and subject interest level. Finally, a more detailed investigation of laptop use outside of class is needed to examine the potential benefits of distracting laptop behaviour such as providing mental breaks, indirect learning, and social supports.

\section{References}

Aguilar-Roca, N. M., Williams, A. E., \& O’Dowd, D. K. (2012). The impact of laptop-free zones on student performance and attitudes in large lectures. Computers \& Education, 59(4), 1300-1308. doi:10.1016/j.compedu.2012.05.002

Andreou, C. (2007). Understanding procrastination. Journal for the Theory of Social Behaviour, 37(3), 183-193. doi: 10.1111/j.1468-5914.2007.00331.x

Arend, B. D. (2004). New patterns of student engagement. About Campus, 9(3), 30-32. doi: $10.1002 / \mathrm{abc} .98$

Awwad, F., \& Ayesh, A. (2013). Effectiveness of laptop usage in UAS university undergraduate teaching. The Turkish Online Journal of Educational Technology, 12(2), 77-88. 
Barak, M., Lipson, A., \& Lerman, S. (2006). Wireless laptops as means for promoting active learning in large lecture halls. Journal of Research on Technology in Education, 38(3), 245-263.

Bruner, J. (1996). The culture of education. Cambridge: Harvard University Press.

Barrows, H. S. \& Tamblyn, R. M. (1980). Problem-based learning: An approach to medical education. New York: Springer.

Claessens, B. J. C., van Eerde, W., Rutte, C. G., \& Roe, R. A. (2007). A review of the time management literature. Personnel Review, 36(2), 255-276.

doi:10.1108/00483480710726136

Dahlstrom, E., Walker, J.D., \& Dziuban, C, M. (2013). The ECAR study of undergraduate students and information technology (Research Report). Louiseville, CO: EDUCAUSE Center for Analysis and Research, Retrieved from https://net.educause.edu/ir/library/pdf/ERS1302/ERS1302.pdf

Demb, A., Erickson, D., \& Hawkins-Wilding, S. (2004). The laptop alternative: Student reactions and strategic implications. Computers \& Education, 43(4), 383-401. doi: 10.1016/j.compedu.2003.08.008

Eitelbacj, D. (2012, Jan 30). Average windows laptop costs \$456, down 14 percent in 24 months. Retrieved from http://blog.laptopmag.com/average-windows-laptop-costs-456-down-14percent-in-24-months

Fried, C. B. (2008). In-class laptop use and its effects on student learning. Computers \& Education, 50(3), 906-914. doi: 10.1016/j.compedu.2006.09.006

Gaudreau, P., Miranda, D., \& Gareau, A. (2014). Canadian university students in wireless classrooms: What do they do on their laptops and does it really matter? Computers \& Educations, 70(3), 245-255. doi: dx.doi.org/10.1016/j.compedu.2013.08.019

Gagné, R. (1985). The conditions of learning. New York: Holt Reinhart and Winston.

Grace-Martin, M., \& Gay, G. (2001). Web browsing, mobile computing and academic performance. Educational Technology and Society, 4(3), 95-107. Retrieved from http://www.ifets.info/journals/4_3/grace_martin.html

Hembrooke, H., \& Gay, G. (2003). The laptop and the lecture: The effects of multitasking in learning environments. Journal of Computing in Higher Education, 15(1), 46-64.

Hutchins, E. (1995). How a cockpit remembers its speeds. Cognitive Science, 19, 265-288.

Johnson, D., Johnson, R. (1994). Learning together and alone, cooperative, competitive, and individualistic learning. Needham Heights, MA: Prentice-Hall.

Kay, R.H., \& Lauricella, S. (2011). Exploring the benefits and challenges of using laptop computers in higher education classrooms: A formative analysis. Canadian Journal of 
Learning and Technology, 37(1). Retrieved from http://www.cjlt.ca/index.php/cjlt/article/view/565/299

Kolar, R. L., Sabatini, D. A., \& Fink, L. D. (2002). Laptops in the classroom: Do they make a difference? Journal of Engineering Education, 91(4), 397-401. doi: 10.1002/j.21689830.2002.tb00723.x

Kraushaar, J. M., \& Novak, D. C. (2010). Examining the effects of student multitasking with laptops during the lecture. Journal of Information Systems Education, 21(2), 241-251.

Lauricella, S. \& Kay, R. H. (2010). Assessing laptop use in higher education classrooms: The laptop effectiveness scale (LES). Australian Journal of Educational Technology, 26(2), 151-163. Retrieved from http://www.ascilite.org.au/ajet/ajet26/lauricella.pdf

Lave, J., \& Wenger, E. (1998). Communities of practice: learning, meaning, and identity. Cambridge: University Press.

Lindroth, T., \& Bergquist, M. (2010). Laptopers in an educational practice: Promoting the personal learning situation. Computers \& Education, 54(2), 311-320. doi: 10.1016/j.compedu.2009.07.014

Mackinnon, G. R. (2002). Judging the constructive impacts of communication technologies: A business education study. Education and Information Technologies, 7(2), 127-135. Retrieved from http://www.acadiau.ca/ gmackinn/pub/pdf/EIT.pdf

McCrea, B. (2010). 5 higher educations trends to watch. Campus Technology. Retrieved from http://campustechnology.com/Articles/2009/12/09/5-Higher-Ed-Tech-Trends-To-Watchin-2010.aspx?p=1.

McCreary, J. R. (2009). The laptop-free zone.. Valparaiso University Law Review, 43, 1-87.

McWilliams, G. (2005). The laptop backlash. The Wall Street Journal (October 14), B1.

Miles, M. B. \& Huberman, A. M. (1994). Qualitative data analysis ( $2^{\text {nd }}$ ed.). Sage Publications: Thousand Oaks, CA

Montgomery, K. C. (2009). Generation digital. MIT Press: MA.

Nicol, D. J., \& MacLeod, I. A. (2005). Using a shared workspace and wireless laptops to improve collaborative project learning in an engineering design class. Computers \& Education, 44(4), 459-475. doi: 10.1016/j.compedu.2004.04.008

Palfrey, J. \& Gasser, U. (2008). Born digital. Basic Books: NY.

Perry, M. (2003) Distributed Cognition. In J.M. Carroll (Ed.) HCI Models, theories, and frameworks: Toward an interdisciplinary science (pp. 193-223). San Francisco: Morgan Kaufmann Publishers.

Prensky, M. (2010). Teaching digital natives. Thousand Oaks, CA: Corwin. 
Sana, F., Weston, T., \& Cepeda, N. J. (2013). Laptop multitasking hinders classroom learning for both users and nearby peers. Computers \& Education, 62(1), 24-31. doi: 10.1016/j.compedu.2012.10.003

Savery, J. R., and Duffy, T. M. (1995). Problem based learning: an instructional model and its constructivist framework. Educational Technology, 35, 31-38.

Skolnik, R., \& Puzo, M. (2008). Utilization of laptop computers in the school of business classroom. Academy of Educational Leadership Journal, 12(2), 1-10.

Schwartz, J. (2003). Professors vie with Web for class's attention. New York Times (January 2), A1. Retrieved from http://www.nytimes.com/2003/01/02/us/professors-vie-with-web-forclass-s-attention.html

Tapscott, D. (2008). Grown up digital: How the Net generation is changing your world. McGraw-Hill: NY.

Vygotsky, L.S. (1978). Mind and society: The development of higher mental processes. Cambridge, MA: Harvard University Press.

Weaver, B. E., \& Nilson, L. B. (2005). Laptops in class: What are they good for? What can you do with them? New Directions in Teaching and Learning, 101, 3-13. doi:10.1002/tl.181

Wordman, P. B. (2012, Feb 23). 2013 Notebooks, ultrabooks, laptops, ultrathins at a glance. Retrieved from http://blog.parts-people.com/2012/02/23/2013-notebooks-ultrabookslaptops-ultrathins-at-a-glance/

Wurst, C., Smarkola, C., \& Gaffney, M. A. (2008). Ubiquitous laptop usage in higher education: Effects on student achievement, student satisfaction, and constructivist measures in honors and traditional classrooms. Computers \& Education, 51(4), 1766-1783. doi: 10.1016/j.compedu.2008.05.006

Young, J. R. (2006). The fight for classroom attention: professor vs. laptop. Chronicle of Higher Education (June 2), A27-A29. 


\section{Appendix A: Student Laptop Use Survey}

\section{Background}

1. Gender?

2. What year of university are you in?

3. What course are you taking?

4. What is your average grade in this course?

5. Overall, how interesting to you find the classes in this course Not at all interesting, Somewhat Interesting, Interesting, Very Interesting

6. How comfortable are you with using computers? Not at all comfortable. Somewhat Comfortable, Comfortable, Very Comfortable

7. How many hours per day do you spend actually using your laptop computer?

\section{Academic Use During Class}

8. How often do you do the following activities DURING this class?

(Never, Rarely, Sometimes, Frequently, Very Frequently)

Active Use

a. Search the web for academic purposes

b. Use online interactive tools (e.g., learning objects. Applets)

c. Participate in Online Surveys

d. Communicate with peers for academic purposes (e.g., IM, email)

e. Using a software program for academic purposes (e.g., Excel)

Passive Use

f. Taking notes during the lecture

g. Use the notes posted by the instructor

h. Following a PowerPoint on the laptop

9. Overall what are the biggest benefits to having a laptop in class for this course? Why?

\section{Non-Academic Use During Class}

10. How often do you do the following activities DURING this class?

(Never, Rarely, Sometimes, Frequently, Very Frequently)

Information Search

a. Search the web for personal reasons

Entertainment

b. Play games

c. Watch movies

d. Watch short video clips (e.g., YouTube)

Social Networking

e. Go on Facebook

f. Use Twitter

g. Use Instant messaging (such as MSN, Skype) for non-academic purposes

h. Use email for non-academic purposes

11. Overall what are the biggest distractions in having a laptop in class for this course? Why? 


\section{Academic Use Outside of Class}

12. How important are the following laptop based activities in supporting your learning

OUTSIDE of class?

(Never, Rarely, Sometimes, Frequently, Very Frequently)

Productivity

a. Organizing course notes and materials

b. Online interactive activities (e.g., learning objects. Applets)

c. Using a software program for academic purposes (e.g., Word, Excel)

Collaboration

d. Sharing notes and course resources

e. Communicate with peers for academic purposes (e.g., instant messaging, email)

f. Working with peers on assigned group work

g. Getting help from peers on computer related tasks

Research

h. Search the web for academic purposes

i. Searching the university library databases for articles/books

13. Overall what are the biggest benefits to having a laptop OUTSIDE class? Why?

\section{Non-Academic Use Outside of Class}

14. How distracting are the following activities with respect to preventing you from completing your school work?

(Never, Rarely, Sometimes, Frequently, Very Frequently)

Information Search

a. Search the web for personal reasons

Entertainment

b. Play games

c. Watch movies

d. Watch short video clips (e.g., YouTube)

Social Networking

e. Go on Facebook

f. Use Twitter

g. Use Instant messaging (such as MSN, Skype) for non-academic purposes

h. Use email for non-academic purposes

15. Overall what are the biggest distractions to having a laptop OUTSIDE class? Why? 


\section{Author}

Robin Kay has published over 120 articles, chapters and conference papers in the area of computers in education, is a reviewer for five prominent computer education journals, and has taught computers, mathematics, and technology for over 20 years at the high school, college and university level. Current projects include research on laptop use in teacher education, learning objects, classroom response systems, e-learning, video podcasts, gender differences in computer related behaviour, emotions and the use of computers, and factors that influence how students learn with technology. He completed his Ph.D. in Cognitive Science (Educational Psychology) at the University of Toronto, where he also earned his masters degree in Computer Applications in Education. He is currently an Associate Professor in the Faculty of Education at the University of Ontario Institute of Technology in Oshawa, Canada. Email: robin.kay@uoit.ca.

Dr. Sharon Lauricella is an award-winning university professor at UOIT. She has published and presented research on food and spiritual communication, social media and the use of laptops in higher education.

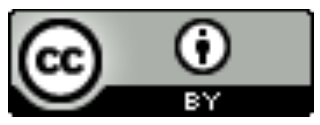

This work is licensed under a Creative Commons Attribution 3.0 License. 